\title{
Personal Traits, Familial Characteristics and Success in the Labor Market: A Survey Study of Christian Labor Force in Pakistan
}

\author{
Sehrish Haroon, Faiza Azhar Khan and Naheed Zia Khan ${ }^{1}$
}

\begin{abstract}
In Pakistan, state of minorities still remains largely unexplored in a number of dimensions. Specifically, their social status and economic contribution. This study is first of its kind in that it analyzes the determinants of labour market positioning and earnings of Christian workforce of the country. The analysis is carried out by developing a study instrument, which focuses on socioeconomic characteristics of the parental family and personal characteristics of a worker. A purposive sample of 246 Christian members of labour force employed in upper and middle rungs of job hierarchies is taken from twin cities, Rawalpindi/Islamabad. Determinants of job market positioning have been examined by applying logistic regression analysis, while OLS regression has been used to investigate the determinants of income. Results of logistic regression suggest that socioeconomic status of parents is a major factor in determining occupational success of the children of Christian families in Pakistan, as 4 of the 9 respective variables are found significant in statistical estimation. On the other hand, estimates of OLS regression show that asset ownership of their parents along with personal educational achievement significantly determine higher earnings of Christian workforce in Pakistan. The study leads to the conclusion that further research warrants to be carried out on social and economic issues of Christian citizens of Pakistan, specifically targeting the vast numbers lying on the margins of social hierarchy. This essentially requires development of a comprehensive national database on demographic and economic characteristics of all religious minorities of the country. Such an initiative will help assess their state of assimilation in mainstream society which in turn will help devise most efficient and effective interventions.
\end{abstract}

Keywords: Christian workforce, Logistic regression, Study instrument, Socioeconomic status of parents

JEL Classification: J15, J01

\footnotetext{
${ }^{1}$ The authors are Lecturer at the Department of Public Administration, Assistant Professor and Professor at Department of Economics, Fatima Jinnah Women University, Rawalpindi, respectively. Corresponding author's Email: faiza.fjwu@gmail.com.
} 


\section{Introduction}

Minorities are considered to have special significance and rights in almost all modern states. Multiculturalism and cultural relativity are universally prevalent values of present times, while xenophobic and ethnocentric attitudes are considered to have lost their relevance in a fast globalizing world. Denominations for minorities range from religious/sectarian to ethnic/racial differences distinguishing the respective communities from the mainstream of a country. Indeed, the principles underlying the edifice of contemporary secularism underscore the rights of minorities to uphold and cherish their cultural values and racial descents respectively in par with the corresponding phenomena belonging to the mainstream society. That said, the latter essentially and overwhelmingly prevails everywhere including the Western countries.

Intricately knitted social fabric of Pakistan is glossed with its minority groups. Although not a secular republic, religious minorities in Pakistan have a lot more cultural affinity with mainstream of the country than that of the Western secular states. However, little or no work exists on the economic dynamics of the religious minority groups of Pakistan's labour force. This paper is devoted to this highly important inquiry. Christianity is the denomination for the focal minority group of this study.

Almost $96 \%$ of the population in Pakistan is Muslim, while Christians are the largest religious minority nearing $2 \%$ of country's total headcount. ${ }^{2}$ Christian members of Pakistan's labour force represent almost all professional categories including legislative, judicial, civil and military services. ${ }^{3}$ Indeed, Christians are a significant part of Pakistan's citizenry since her creation in 1947. Moreover, the Community claims an ancient heritage in the Sub-continent, as the origin of Christian faith in India conforms with the origin of similar faith in Europe early in the $1^{\text {st }}$ millennium. ${ }^{4}$ That said, the Christianity in India flourished with the arrival of missionaries who followed the European commercial expeditions from $15^{\text {th }}$ century onwards.

\footnotetext{
2 http://www.pbs.gov.pk/sites/default/files//tables/POPULATION\%20BY\%20RELIGION.pdf, accessed on November 23, 2015, at 11:00 hrs.

${ }^{3}$ Justice Alvin Robert Cornelius: Served as the 4th Chief Justice of Pakistan from 1960 to 1968 See more at: http://www.christiansinpakistan.com/pakistani-christian-hero-justice-alvin-robertcornelius/\#sthash.zaj7tIIM.dpuf

${ }^{4}$ St. Judas Thomas, a carpenter and a disciple of Jesus Christ, is believed to have introduced Christian faith in ancient India. See, http://adaniel.tripod.com/Christianity.htm, accessed on November 23, 2015, at 12:30 hrs.
} 
Although a vast body of literature exists on the broad theme of this study which underscores the effect of demographic characteristics on an individual's success in the labour market, hardly any work has been carried out on indigenous communities existing alongside the majority population with insufficient cultural assimilation and informal but very rigid barriers for structural assimilation. Such is the case of Christians in Pakistan. This study is, therefore, first of its kind and relies on the primary data collection.

The argument of this paper is structured around three parts. Part I provides a brief review of the literature that highlights numerous aspects of performance in the labour market. This is followed by Part II which contains the information on methodology employed and data used for empirical analysis. Finally, Part III presents the estimation of models and discussion of results.

\section{Perspectives from Literature}

The theory of dualistic labour market, pioneered by Doeringer and Piore (1972), segments the labour market into primary and secondary with respect to the job characteristics in terms of opportunities for growth, security, pay packages, and reputation. Wage differential is widely considered as one of the common parameters of segregation [Basch and Molina (1996)]. Empirical evidence exists of the greater likelihood of women and minorities finding employment in secondary labour markets [Altonji and Blank (1999)].

In addition to primary and secondary segments, the theory of labour market segmentation introduces an intermediary segment [Daw and Hardie (2012)]. This strand of theory appears to draw upon a much earlier study which divides the labour market into separate sub-markets with widely dissimilar features [Reich et al. (1973)], while another simultaneously published work describes labour market segmentation as a historical process driven by political and economic forces [Bowles (1973)].

The foregoing arguments correspond to the larger part of Christian labour force in Pakistan. The historical processes dating back to the ancient Indian society have locked majority of the working age members of Christian community into the secondary labour market and/or lower rungs of the job hierarchies. Unfortunately, no resources have been provided on part of the responsible agencies in the form of nationwide statistics necessary for carrying out research on critically important and diverse characteristics of the working population of minority groups in Pakistan. 
This study, therefore, subscribes to the family investment model which links parent's socioeconomic status (SES) to the labour market success of individuals. ${ }^{5}$

Favourable SES of parents usually corresponds with the greater emphasis placed on providing the children access to high quality education [Hirschman (1982)]. According to Conger and Donnellan (2007), the SES of parents directly determines the conditions which significantly affect an individual's welfare in work life. Their empirical findings suggest considerable differences in parenting styles and child support strategies corresponding to SES of the families. ${ }^{6}$ Several other empirical studies also underscore the SES of parents in determining economic success of children as adults [Schneider and Lee (1990); Sanders (2002); Hello et al. (2004); Hazans et al. (2008); Abada et al. (2009)].

Nonetheless, an all-encompassing support is not extended to SES of parents by studies focusing on the economic prospects of ethnic minorities [Borjas (1987); Fan (2002)]. Almost all such studies suggest the need for direct interventions and indirect strategies to enhance economic prospects and promote cultural assimilation respectively of ethnic minorities. The empirical analysis carried out by Abada et al. (2009) also appears to support the strategies for cultural assimilation, as their findings show that even those young people of ethnic minorities who outcompete intra-group peers, in many cases still do not come at par with the mainstream group. It therefore follows that, apart from family's SES, social affinity and sense of belongingness with peers is a major driving factor for success in education which, in turn, paves the way for success in the labour market. Similarly, while simultaneously underscoring the significance of educational attainment for favourable positioning in the job market, Fan (2002) identifies the need for laws to promote economic wellbeing of minorities. Keeping in perspective the convincing arguments of group positioning theory, such kind of interventions are highly desirable as well as warranted in Pakistan. ${ }^{7}$

\footnotetext{
${ }^{5}$ Socioeconomic status refers to a family's positioning within a social hierarchy, relative to access or control over social capital and physical assets ownership [see, Sirin (2005)].

${ }^{6}$ The argument of this work appears to draw upon Bradley et al. (2001) who suggested a positive relationship between family income and educational attainment of children. Conger and Donnellan (2007), however, introduced the phenomenon of Social Selection whereby the personal characteristics of an individual help compensate for lower SES of parents.

${ }^{7}$ The debate on group positioning started with Blumer's theory. According to its proponents, the ideas, interaction, identity, and values are determined historically, while long-term interaction among groups plays part in prerogatives earned or offered to a minority community [see, Blumer (1969); Douglas (2008)].
} 
Finally, as mentioned earlier, the broad base for the research design of this study remains the theory of social causation which highlights the combined influence of social and economic conditions for effective performance and development of an individual [Conger and Donnellan (2007)]. Therefore, parental SES of the members of a minority group plays imperative part in their educational [Borjas (1987)] and other personal attainments including ability to pursue a rewarding occupation in the labour market [Sirin (2005)] and enhanced opportunities for upward social mobility [Kim and Kulkarni (2009)].

\section{Methodology and Data}

This part is devoted to introducing the methodology and data of this paper. The data used for empirical analysis, Part III, is both original and unique in that its source is primary with target population not addressed by the earlier researches carried out on similar topics. The problem formulation for empirical analysis employs standard analytical techniques for econometric estimation. Two single equation models are formulated to test the following research hypothesis:

The labour market positioning of Christian workforce is positively related with socioeconomic characteristics of their parents, while personal traits also determine earnings of the employees.

In order to test the first part of research hypothesis, following general form of the model is formulated:

$\mathrm{OR}_{\mathrm{i}}=\mathrm{f}\left(\mathrm{Edu}_{\mathrm{i}}, \operatorname{Exp}_{\mathrm{i}}, \mathrm{ME}_{\mathrm{i}}, \mathrm{FE}_{\mathrm{i}}, \mathrm{FO}_{\mathrm{i}}, \mathrm{MO}_{\mathrm{i}}, \mathrm{SLP}_{\mathrm{i}}, \mathrm{AOP}_{\mathrm{i}}, \mathrm{EMP}_{\mathrm{i}}, \mathrm{DPF}_{\mathrm{i}}, \mathrm{ODP}_{\mathrm{i}}\right)$

The specific form of the model with dichotomous measure of the left-hand side variable is given as:

$\mathrm{OR}_{\mathrm{i}}=\alpha_{0}+\alpha_{1} \mathrm{Edu}_{\mathrm{i}}+\alpha_{2} \mathrm{Exp}_{\mathrm{i}}+\alpha_{3} \mathrm{ME}_{\mathrm{i}}+\alpha_{4} \mathrm{FE}_{\mathrm{i}}+\alpha_{5} \mathrm{FO}_{\mathrm{i}}+\alpha_{6} \mathrm{MO}_{\mathrm{i}}+\alpha_{7} \mathrm{SLP}_{\mathrm{i}}+\alpha_{8} \mathrm{AOP}_{\mathrm{i}}+$ $\alpha_{9} \mathrm{EMP}_{\mathrm{i}}+\alpha_{10} \mathrm{DPF}_{\mathrm{i}}+\alpha_{11} \mathrm{ODP}_{\mathrm{i}}+\mu_{\mathrm{i}}$

Where,

$\mathrm{OR}_{\mathrm{i}}=$ Occupational rung ( 0 for upper rungs, 1 for middle rungs)

$\mathrm{Edu}_{\mathrm{i}}=$ Education of the respondent (years of schooling)

$\operatorname{Exp}_{\mathrm{i}}=$ Work experience of the respondent (in completed years)

$\mathrm{ME}_{\mathrm{i}}=$ Mother's education (years of schooling)

$\mathrm{FE}_{\mathrm{i}}=$ Father's education (years of schooling)

$\mathrm{FO}_{\mathrm{i}}=$ Father's occupation (self-employed vs. wage earner) 
$\mathrm{MO}_{\mathrm{i}}=$ Mother's occupation (homemaker vs. wage earner)

$\mathrm{SLP}_{\mathrm{i}}=$ Standard of living in parental home (composite weighted index form derived measure for household's consumption of durables including domestic appliances, automobiles and electronics)

$\mathrm{AOP}_{\mathrm{i}}=$ Asset ownership of parental home (composite weighted index form derived measure for ownership of any land form, residential (other than dwelling), commercial or agricultural and gold more than 100 grams)

$\mathrm{EMP}_{\mathrm{i}}=$ Earning members in parental home (earners headcount)

$\mathrm{DPF}_{\mathrm{i}}=$ Dependents in parental family (headcount of dependent family members)

$\mathrm{ODP}_{\mathrm{i}}=$ Ownership of dwelling by parental family (binary scale)

$\mu_{\mathrm{i}}=$ Stochastic error term

Another model is formulated to test the second part of the research hypothesis as:

$\mathrm{Y}_{\mathrm{i}}=\mathrm{f}\left(\mathrm{Age}_{\mathrm{i}}, \mathrm{Gen}_{\mathrm{i}}, \mathrm{Edu}_{\mathrm{i}}, \mathrm{Exp}_{\mathrm{i}}, \mathrm{WH}_{\mathrm{i}}, \mathrm{ES}_{\mathrm{i}}, \mathrm{JT}_{\mathrm{i}}, \mathrm{AOP}_{\mathrm{i}}, \mathrm{MS}_{\mathrm{i}}\right)$

The specific form can be written as:

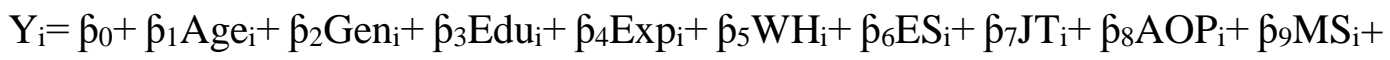
$\mu_{2 \mathrm{i}}$

Where,

$\mathrm{Y}_{\mathrm{i}}=$ Monthly income of the respondent (in thousands of rupees)

$\mathrm{Age}_{\mathrm{i}}=$ Age of the respondent in completed years

Gen $_{\mathrm{i}}=$ Gender as a binary measure $(1=$ Female $)$

$\mathrm{WH}_{\mathrm{i}}=$ Daily working hours of the respondent

$\mathrm{ES}_{\mathrm{i}}=$ Public vs. Private sector employment as a binary measure

$\mathrm{JT}_{\mathrm{i}}=\mathrm{Job}$ turnover (number of job switching)

$\mathrm{MS}_{\mathrm{i}}=$ Marital status as a binary measure (1= Ever married)

The denominations of variables Edu, Exp and AOP are the same as those of the earlier model. The derived measures for AOP and SLP represent SES of parental family in this study and are expected to serve the purpose of exploring the effect that they may have on the educational and professional achievements of respondents. Also, these two variables serve as proxy for income of the parental home, because majority of the respondents failed to provide a consistent and 
reliable corresponding measure. Finally, working hours and experience often underscore the size of earnings [Constant and Massey (2005)], while age, education, marital status, gender and parents' education are widely used variables in similar studies [Wong and Hirschman (1983); Sandefur and Pahari (1989); Constant and Massey(2005); Hazans et al.(2008); Kim and Kulkarni(2009); Abada et al.(2009)].

Delimitation of this survey study are:

- Purposive sampling;

- Sample taken from twin cities of Rawalpindi/Islamabad, Pakistan;

- Target population is formal sector Christian employees in health, education, finance, aviation and communication sectors.

A study instrument was developed and vetted by the first and third author respectively. However, former is to be fully credited for enormous and painstaking effort of data collection, a process spanning over more than two months of labourious local travelling and interviewing the respondents in person. ${ }^{8}$

The initial plan aimed at reaching out 300 respondents with equal representation of the Christian workforce belonging to upper and middle rungs of job hierarchies. However, unavoidable constraints, which very often limit the scope of survey research, compromised both sample size and its desired stratification. The final data set therefore records the information provided by 246 workers; 136 and 110 employed in upper rungs and middle rungs respectively. ${ }^{9}$ Similarly, sample stratification with respect to age and gender variables was also not feasible because

\footnotetext{
${ }^{8}$ Notwithstanding the argument of alleged bias of the interview method, the pilot survey, initiated with self-administered questionnaire, underscored the need for having recourse to the interview as the respondents either left some of the questions unanswered or their answers did not correspond with direct measurement of the respective variables. Moreover, since the measurements of all but two variables, representing SES of parental family, are based on true values, the alleged bias of the interview method ought to be considered minimal for this study.

${ }^{9}$ Selected sample is representative of the Christian workforce employed in a wide range of professions in the formal sector industries including health, education, finance, aviation and communication, as mentioned in the delimitation of study. Their categorization into upper rungs and middle rungs of job hierarchies underscores a consistent, though arbitrary, standard applied by this study. It is based on a directly measured true value which is the monthly salary package of respondents: Formal sector job not involving manual labour and monthly income below or equal to Rs. 37,113/- is identified with middle rungs, while upper rungs include those formal sector employees who have a monthly salary package above Rs. 37,113/-. Latter is the threshold commensurate with monthly take home salary of public sector BS-17 workers in FY 2013-14.
} 
of social and logistical constraints to reach out the respondents belonging to a population which is not part of the mainstream society of Pakistan. Table 1 and Table 2 in the following vividly introduce the members of the sample.

The information listed in Table 1 reveals that the sample is representative of youth and middle-aged workers as over $67 \%$ of the respondents lie in the age ranges, 26-50 years. Given that $18 \%$ of the respondents are above the age of 50 years and $24 \%$ belong to the age range of $41-50$ years, the sample is fairly representative of the workers who have spent most of their work life as employees in the middle rungs of job hierarchies. This is also evident from the information recorded on the educational achievement since less than half of the respondents reported more than 14 years of schooling, while 9 of the category exhibit education less than 10 years of schooling. As expected, more than half of the middle rung workers have education above school level but only up to 14 years of schooling. Similarly, largest number of respondents in this category, over $78 \%$, have a salary package above 16 thousand rupees a month, while about half of the respondents earn more than 25 thousand rupees a month. Finally, although most of the workers in this category are employed in the private sector, 90\% reported length of the workday as 8 hours which is commensurate with the public sector.

Table 2 records major demographic characteristics of members of the sample employed in upper rungs of the job hierarchies. Contrary to the respondents reporting for middle rungs of job hierarchies, older members of the sample, above 50 years of age, in this category are the largest group, about one third of the total. This information is commensurate with the work experience since over $43 \%$ of the respondents employed in upper rungs of job hierarchies have spent a work life which spans over more than 20 years. Given that only $11 \%$ of the respondents in this category have income below 40 thousand rupees a month while about one third have educational achievement lying in the range of 10-14 years of schooling, it appears that quite a few of the workers have made to the upper rungs of job hierarchy through vertical mobility with on the job experience. That said, the figures listed in Table 2 also reveal higher educational achievement, more than 14 years of schooling, of over two third of the respondents in this category which, in turn, may be credited for higher monthly income, more than 80 thousand rupees, for many among them. However, measured answers to such and many other questions are expected to be furnished by the estimations carried out in Part III. 
Personal Traits, Familial Characteristics and Success in the Labor Market: A Survey Study of Christian Labor Force in Pakistan

Table 1: Profile of Respondents Employed in Middle Rungs of Job Hierarchies

\begin{tabular}{|c|c|c|}
\hline Category & Frequency & Percentage \\
\hline \multicolumn{3}{|l|}{ Age } \\
\hline Below 25 & 18 & 16.4 \\
\hline $26-40$ & 50 & 45.4 \\
\hline $41-50$ & 24 & 21.8 \\
\hline Above 50 & 18 & 16.4 \\
\hline \multicolumn{3}{|l|}{ Gender } \\
\hline Male & 73 & 66.4 \\
\hline Female & 37 & 33.6 \\
\hline \multicolumn{3}{|l|}{ Education (years of schooling) } \\
\hline Below 10 & 9 & 8.2 \\
\hline $11-14$ & 53 & 48.2 \\
\hline Above 14 & 48 & 43.6 \\
\hline \multicolumn{3}{|l|}{ Marital Status } \\
\hline Never married & 42 & 38.2 \\
\hline All other & 68 & 61.8 \\
\hline \multicolumn{3}{|l|}{ Employer } \\
\hline Public sector & 25 & 22.7 \\
\hline Private sector & 85 & 77.3 \\
\hline \multicolumn{3}{|l|}{ Work Experience (years) } \\
\hline Below 10 & 58 & 52.7 \\
\hline $11-20$ & 19 & 17.3 \\
\hline Above 20 & 33 & 30 \\
\hline \multicolumn{3}{|c|}{ Income (per month rupees in thousands) } \\
\hline Below 15 & 24 & 21.8 \\
\hline $16-25$ & 41 & 37.3 \\
\hline Above 25 & 45 & 40.9 \\
\hline \multicolumn{3}{|l|}{ Job Turnover } \\
\hline Never & 44 & 40.4 \\
\hline Once & 28 & 24.8 \\
\hline More than once & 38 & 34.8 \\
\hline \multicolumn{3}{|l|}{ Working Hours } \\
\hline Less than 8 hrs. a day & 99 & 90 \\
\hline More than 8 hrs. a day & 11 & 10 \\
\hline
\end{tabular}

Source: Survey by the first author.

Finally, other than $A O P$ and SLP, which are composite weighted index form derived measures, all variables included in the models outlined above have true 
values. Table 3 provides the information on SES of respondents' parental families with the help of derived measures taken on AOP and SLP.

Table 2: Profile of Respondents Employed in Upper Rungs of Job Hierarchies

\begin{tabular}{|c|c|c|}
\hline Category & Frequency & Percentage \\
\hline \multicolumn{3}{|l|}{ Age } \\
\hline Below 30 & 19 & 14 \\
\hline $31-40$ & 42 & 30.9 \\
\hline $41-50$ & 31 & 22.8 \\
\hline Above 50 & 44 & 32.3 \\
\hline \multicolumn{3}{|l|}{ Gender } \\
\hline Male & 90 & 66.2 \\
\hline Female & 46 & 33.8 \\
\hline \multicolumn{3}{|c|}{ Education (years of schooling) } \\
\hline $10-14$ & 43 & 31.6 \\
\hline Above 14 & 93 & 68.4 \\
\hline \multicolumn{3}{|l|}{ Marital Status } \\
\hline Never married & 31 & 22.4 \\
\hline All other & 105 & 77.6 \\
\hline \multicolumn{3}{|l|}{ Employer } \\
\hline Public sector & 43 & 31.6 \\
\hline Private sector & 93 & 68.4 \\
\hline \multicolumn{3}{|l|}{ Work Experience (years) } \\
\hline Below 10 & 35 & 25.6 \\
\hline $11-20$ & 42 & 30.8 \\
\hline Above 20 & 59 & 43.6 \\
\hline \multicolumn{3}{|c|}{ Income (per month rupees in thousands) } \\
\hline Below 40 & 15 & 11. \\
\hline $41-80$ & 75 & 55.2 \\
\hline $81-120$ & 21 & 15.4 \\
\hline Above 120 & 25 & 18.4 \\
\hline \multicolumn{3}{|l|}{ Job Turnover } \\
\hline Never & 61 & 44.9 \\
\hline Once & 28 & 20.6 \\
\hline More than once & 47 & 34.5 \\
\hline \multicolumn{3}{|l|}{ Working Hours } \\
\hline Less than $8 \mathrm{hrs}$. a day & 102 & 75 \\
\hline More than 8 hrs. a day & 34 & 25 \\
\hline
\end{tabular}

Source: Survey by the author. 
The figures show that, for both indexes, percentage of respondents with below 15 score is visibly higher for the category employed in middle rungs of job hierarchies. A consistent scenario appears to be there for almost all subsequent ranges of the score on asset ownership of parental family. The pattern remains consistent for the lowest and the second lowest score on SLP. A deviation, however, is observed for the next three ranges; specifically, so for the second highest score. Nonetheless, the highest score on SLP index essentially favors the higher percentage of respondents employed in the upper rungs of job hierarchies.

Table 3: SES of Parental Family: Indexes for AOP and SLP

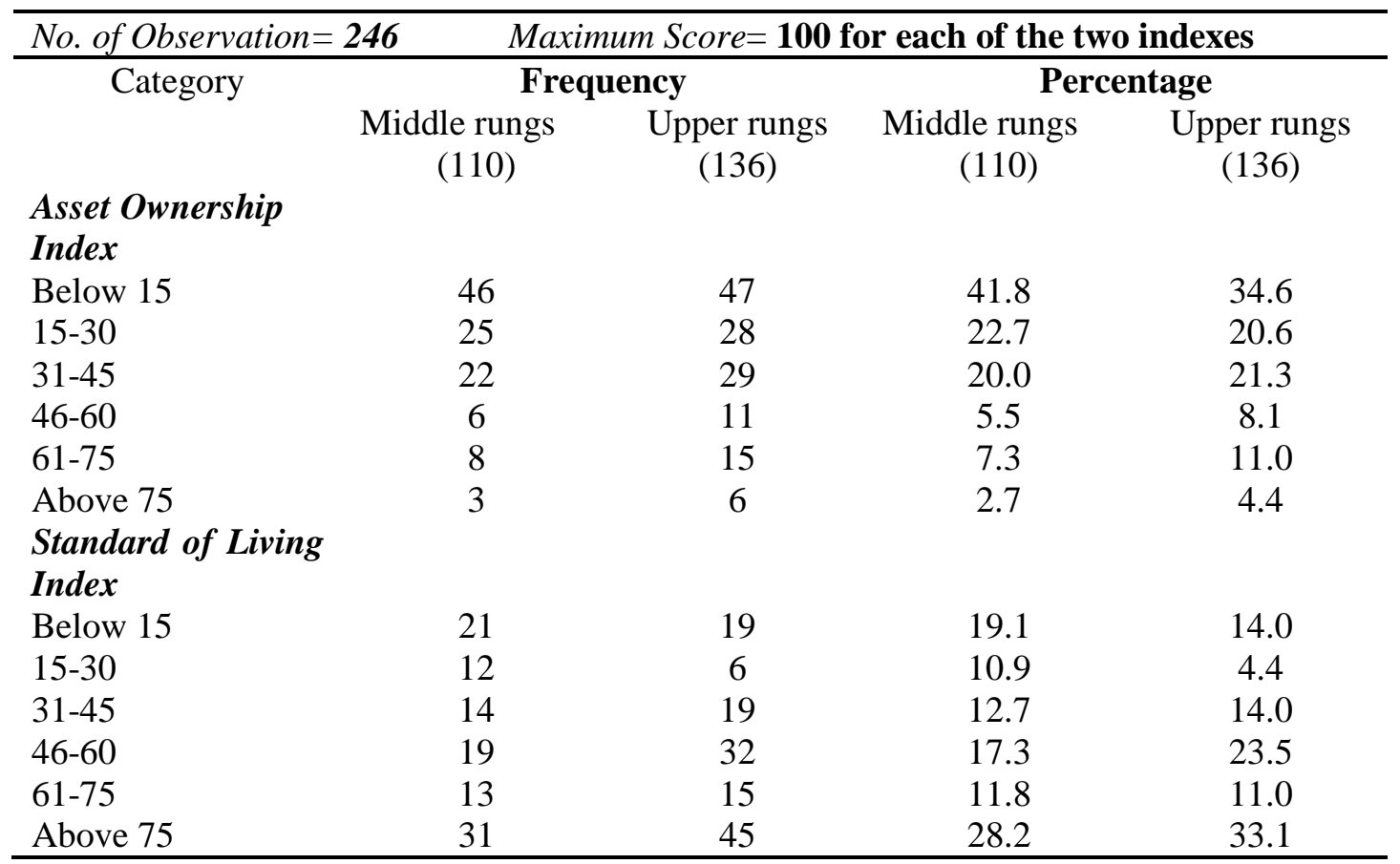

Source: Derived by the authors with the help of survey information.

\section{Estimation of Models and Discussion of Results}

To estimate the models outlined in Part II, widely popular and reliable econometric techniques are applied, namely; Logistic Regression and Ordinary Least Squares (OLS) technique for first and the second model respectively. Computer package used for estimation is Stata 12.0. The results are reported in Table 4 and Table 5.

The first part of the research hypothesis relates the job market positioning of Christian members of Pakistan's labour force with the socioeconomic 
characteristics of their parental family. Other than education, Edu, and experience, Exp, all variables included in the logistical regression model underscore the characteristics of respondents' parental families. The corresponding estimates reported in Table 4 show that 4 of the 9 variables representing socioeconomic characteristics of parental family turn out to be significant. Of the two variables standard of living in parental home, SLP, and asset ownership of parental family, AOP, taken as proxy for SES of parental family, the former is significant at 5\% level of significance. The other variables which stand out for parental characteristics are earning members in parental family, EMP, dependents in parental family, DPF, and ownership of dwelling by parent's family, ODP; all three significant at $10 \%$ level of significance.

Figures listed in Table 4 reveal that a unit increase in standard of living in parental home, SLP, raises the log of odds ratio of being employed in higher rungs of job hierarchy by 0.018 units. With $1 \%$ increase in SLP, probability of being employed in higher occupational rungs increases by $0.004 \%$. On the other hand, the relevance of asset ownership of parental family, AOP, which though carries a theoretically consistent sign, is not significant. Nonetheless, given the generally disadvantaged economic position of Christian community in Pakistan, specifically for parental generation of the respondents, another important variable, not included in the indexes derived for AOP and SLP, is ownership of dwelling by parental family, ODP. The estimated coefficient of this variable carries a positive sign and is significant at $10 \%$ level of significance, showing that if parental family is having ownership of dwelling, the log of odds ratio of working in higher rungs of job hierarchy is higher by 0.64 units. Probability of belonging to this category of workers is $0.15 \%$ higher for those respondents whose parents had the ownership of dwelling. The variables mother's occupation, MO, father's occupation, FO, father's education, FE, and mother's education, $\mathrm{ME}$, are not only the part of socioeconomic characteristics of parental family, they also indirectly contribute to its socioeconomic status, SES. Although all four turn out insignificant for this study, MO, FO, and FE carry theoretically right signs. Therefore, overall findings of the logistical regression estimates reported in Table 4 conform with the earlier studies which suggest positive relationship of higher SES of parental family with occupational success of the children [Conley and Glauber (2007); Hannah et al.(1986); Wilson and Portes (1980); Kim and Kulkarni (2009); Abada et al.(2009); Hirschman (1982); Cogner and Donnellan (2007)]. Other variables representing parental family's socioeconomic profile are earning members in parental family, $E M P$, and dependents in parental family, $D P F$, both carrying significant estimated coefficients with negative and positive signs respectively, as listed in Table 4. 
Personal Traits, Familial Characteristics and Success in the Labor Market: A Survey Study of Christian Labor Force in Pakistan

Table 4: Determinants of Success in the Labour Market: Logit Estimates

\begin{tabular}{|c|c|c|c|}
\hline \multicolumn{2}{|c|}{ 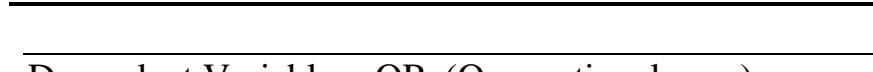 } & \multicolumn{2}{|c|}{ No. of Observations $=246$} \\
\hline $\begin{array}{l}\text { Dependent Variable }=\mathrm{OR}_{\mathrm{i}}(\text { Occupationa } \\
\text { Upper rungs }=1, \text { Middle rungs }=0\end{array}$ & ung) & & \\
\hline Variable & Coefficient & Z-Statistics & $\begin{array}{l}\text { Marginal } \\
\text { Effects }\end{array}$ \\
\hline Constant & $-7.823^{* * *}$ & -4.87 & 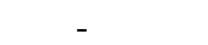 \\
\hline $\mathrm{Edu}_{\mathrm{i}}$ (Education, years of schooling) & $0.371^{* * *}$ & 4.13 & $\begin{array}{c}0.090^{* * *} \\
(4.18)\end{array}$ \\
\hline $\operatorname{Exp}_{\mathrm{i}}$ (Work experience in years) & $0.068^{* * *}$ & 3.65 & $\begin{array}{c}0.016^{* * *} \\
(3.37)\end{array}$ \\
\hline $\mathrm{ME}_{\mathrm{i}}$ (Mother's education) & -0.025 & -0.49 & $\begin{array}{l}-0.006 \\
(-0.49)\end{array}$ \\
\hline $\mathrm{FE}_{\mathrm{i}}$ (Father's education) & 0.037 & 0.67 & $\begin{array}{l}0.009 \\
(0.67)\end{array}$ \\
\hline $\mathrm{FO}_{\mathrm{i}}$ (Father's occupation) & -0.233 & -0.91 & $\begin{array}{l}-0.056 \\
(-0.90)\end{array}$ \\
\hline $\mathrm{MO}_{\mathrm{i}}$ (Mother's occupation) & 0.175 & 0.47 & $\begin{array}{l}0.042 \\
(0.47)\end{array}$ \\
\hline $\begin{array}{l}\mathrm{SLP}_{\mathrm{i}} \text { (Parental family's standard of } \\
\text { living) }\end{array}$ & $0.018^{* *}$ & 2.49 & $\begin{array}{l}0.004^{* *} \\
(2.48)\end{array}$ \\
\hline $\begin{array}{l}\text { AOP }_{i} \text { (Parental family's asset } \\
\text { ownership) }\end{array}$ & 0.011 & 1.50 & $\begin{array}{l}0.002 \\
(1.50)\end{array}$ \\
\hline $\mathrm{EMP}_{\mathrm{i}}$ (No. of earners in parental family) & $-0.460^{*}$ & -1.91 & $\begin{array}{l}-0.112^{*} \\
(-1.91)\end{array}$ \\
\hline $\begin{array}{l}\mathrm{DPF}_{\mathrm{i}} \text { (No. of dependents in parental } \\
\text { family) }\end{array}$ & $0.116^{*}$ & 1.73 & $\begin{array}{l}0.028^{*} \\
(1.73)\end{array}$ \\
\hline $\begin{array}{l}\mathrm{ODP}_{\mathrm{i}} \text { (Parental family's ownership of } \\
\text { dwelling) }\end{array}$ & $0.646^{*}$ & 1.89 & $\begin{array}{l}0.154^{*} \\
(1.94)\end{array}$ \\
\hline
\end{tabular}

Note: ***Significant at $1 \%$ level, $* *$ Significant at $5 \%$ level and $*$ Significant at $10 \%$ level

The variation in signs is theoretically consistent and empirically relevant. The estimated coefficient of EMP shows that a unit change in number of earning members in the family decreases the log of odds ratio of being employed in higher occupational rungs by 0.46 units. Correspondingly, respondents' probability of entering prestigious jobs decreases by $0.11 \%$ with one percent increase in EMP. Indeed, the result obtained on the latter is representative of a large number of poor households in developing countries like Pakistan, where not only every other member of the family is compelled to bring home some earning, they are also 
engaged in low paying multiple occupations [Banerjee and Duflo (2007)]. For the sample of this study, therefore, the resource constraint of more than one earner families appears to limit the ability of parents to secure a future for their children promising prestigious positioning in the job market. Given that majority of the Christian households still belong to economically disadvantaged groups in Pakistan, this finding for parental generation of the respondents is not surprising. Rather, it is further augmented with the positive and significant estimated coefficient of the variable dependents in parental family, DPF. As listed in Table 4, a unit change in $D P F$ increases the log of odds ratio of securing better positioning in the labour market by 0.11 units. Hence $0.02 \%$ increase in probability of joining upper rungs of job hierarchies with one percent increase in $D P F$. Contrary to the empirical literature which suggests a positive relationship between household poverty and dependency ratio [Hadley et al.(2011); Akinbode (2013); Park and Mercado (2015)], the positive sign of DPF in the analysis of this study implies family's access to sufficient economic resources, enough to support dependents as well as to invest in children education to help them secure advantageous positioning in the labour market. This result, though unique, is essentially not misleading in that the sample of this study represents a population for which higher dependency ratio may also imply higher income of the household, not requiring young, elderly and/or women to work for the market.

Finally, obtained results for education, Edu, and experience, Exp, two important personal traits of respondent, are highly significant and carry theoretically right signs. As reported in Table 4, a unit increase in Edu increases the $\log$ of odds ratio of employment in higher rungs by 0.37 units. It is observed that each additional year of $E d u$ increases the probability of prestigious employment by $0.09 \%$; a finding already having plentiful empirical support [Sandefur and Pahari (1989); Conley and Glauber (2007); Hirschman(1982); Fennie and Meng (2002); Semyonov and Epstein (1994); Ream and Palardy (2008); Sirin (2005); Borjas (1987); Poston (1994); Wong and Hirschman (1983)]. Similarly, a year increase in experience, Exp, increases the log of odds ratio of better labour market positioning by 0.06 units, as with one additional year of Exp the probability of a respondent securing employment in higher rungs of the job hierarchy increases by $0.016 \%$. This result extends support to existing empirical studies which highlight the significance of work experience for higher positioning in the labour market [Constant and Massey (2005); Poston (1994); Becker (1962); Tienda and Steir (1992)].

In order to test second part of the hypothesis statement given in Part II, OLS estimates are carried out separately for each of the two categories of workers with 
monthly salary as the left-hand side variable. Results are reported in Table $5 .^{10}$ The only variable which is carrying a positive and significant estimated coefficient for both categories of workers is, education, Edu. The results reveal that a year increase in educational attainment of the employees belonging to upper rungs of job hierarchies increases their salaries by 10.1 units. Although a lower corresponding ratio, 1:1.09, is observed for the other category of workers, this result is also significant at 5\% level of significance. The overall result supports the earlier findings by Kim and Kulkarni (2009), Maxim (1992) and Schneider and Lee (1990).

Other significant results reported in Table 5 vary between the two categories of respondents. While experience, Exp, shows a positive and significant relationship with the monthly salary size of workers employed in middle rungs of job hierarchies, no such relationship is observed for the advantageously positioned category of workers. However, the size of the income of latter is positively related with their age, a result significant at $5 \%$ level of significance.

The results reported in Table 5 are theoretically consistent as they carry the expected sign when the estimated coefficient is significant. For example, while the variable for working hours, $W H$, carries a positive and significant coefficient for the category employed in middle rungs of job hierarchies, it turns out to be insignificant for the workers having better positioning in the job market. On the other hand, the results reveal that while the job turnover, $J T$, is not having any impact on the former category, it is negatively and significantly related with income of the workers employed in upper rungs of job hierarchies. Given the unique character of the sample of this study, this result conceals more than it reveals, and further research needs to be carried out to determine the factors responsible for unfavourable outcome of job turnover observed in Table 5. The only other significant result for upper rungs of job hierarchies is the estimated coefficient of the variable asset ownership of parental family, $A O P$, carrying theoretically right sign but showing no impact on the salary size of the workers employed in lower rungs of job hierarchies. In so far as the variable $A O P$ is one of the two proxies taken for socioeconomic status, SES, of the parental family, this finding is

\footnotetext{
${ }^{10}$ The estimation was also carried out with the total sample of 246 observations. Understandably, results in terms of significance of estimated coefficients of the variables were much better. However, such estimation is misleading in that marked differences exist in the averaged out personal traits between two categories of workers. On the other hand a split sample analysis highlights only those factors which determine the earning differences within each respective category.
} 
consistent with the existing empirical literature [McLeod and Owens (2004); Cogner et al. (2007); Conley and Glauber (2007); Kim and Kulkarni (2009)].

\section{Table 5: Determinants of the Salary Size of Respondents: OLS Estimates}

\begin{tabular}{|c|c|c|}
\hline \multicolumn{3}{|c|}{$\begin{array}{l}\text { Dependent Variable }=\text { Salary per month }\left(\mathrm{Y}_{\mathrm{i}}\right) \\
\text { No. of Observations }=136+110=246\end{array}$} \\
\hline \multirow[t]{2}{*}{ Variable } & \multicolumn{2}{|c|}{ Coefficient } \\
\hline & Upper rungs (136) & Middle rungs (110) \\
\hline Constant & $-211.54^{* * *}$ & 3.480 \\
\hline $\mathrm{Age}_{\mathrm{i}}$ & $1.710^{* * *}$ & -0.178 \\
\hline $\operatorname{Gen}_{\mathrm{i}}($ Gender$)$ & $\begin{array}{c}(2.80) \\
6.872 \\
(0.566)\end{array}$ & $\begin{array}{l}-1.22) \\
-0.829 \\
(-0.47)\end{array}$ \\
\hline$E u_{i}$ (years of schooling) & $\begin{array}{c}10.184^{* * * *} \\
(4.89)\end{array}$ & $\begin{array}{c}1.092 * * \\
(1.99)\end{array}$ \\
\hline $\operatorname{Exp}_{\mathrm{i}}($ Experience $)$ & $\begin{array}{l}0.345 \\
(0.43)\end{array}$ & $\begin{array}{c}0.402^{* *} \\
(2.48)\end{array}$ \\
\hline $\mathrm{WH}_{\mathrm{i}}$ (Daily working hours) & $\begin{array}{l}5.313 \\
(1.36)\end{array}$ & $\begin{array}{l}1.168^{*} \\
(1.94)\end{array}$ \\
\hline $\mathrm{ES}_{\mathrm{i}}$ (public vs. private sector) & $\begin{array}{c}22.283 \\
(1.48)\end{array}$ & $\begin{array}{l}-2.892 \\
(1.38)\end{array}$ \\
\hline $\mathrm{JT}_{\mathrm{i}}(\mathrm{Job}$ turnover $)$ & $\begin{array}{l}-6.034^{* *} \\
(-2.04)\end{array}$ & $\begin{array}{l}0.164 \\
(0.24)\end{array}$ \\
\hline $\mathrm{AOP}_{\mathrm{i}}$ (Asset: parental family) & $\begin{array}{l}0.334^{* *} \\
(1.91)\end{array}$ & $\begin{array}{l}0.014 \\
(0.34)\end{array}$ \\
\hline $\mathrm{MS}_{\mathrm{i}}$ (Marital status) & $\begin{array}{l}-6.743 \\
(-0.72)\end{array}$ & $\begin{array}{l}-0.743 \\
(-0.43)\end{array}$ \\
\hline
\end{tabular}

Note: $* * *$ Significant at $1 \%$ level, $* *$ Significant at $5 \%$ level and $*$ Significant at $10 \%$ level

Finally, the estimated models discussed in the foregoing have been checked for misspecifications. The final estimations are well specified, and results reported in Table 4 and Table 5 are robust for hetroskedasticity.

\section{Conclusions}

Although this paper has not contributed original argument in terms of the relationship between material achievements of children and SES of their parents, the significance of its research content is huge in that the evidence targets a population which is major part of the critical mass of social fabric in Pakistan. It is therefore a beginning which warrants that research is carried out to improve those aspects of religious minorities of the country which help contribute to their 
spontaneous cultural assimilation with the mainstream society. ${ }^{11}$ This is indeed what this paper attempts to highlight and even a modicum of success is expected to go a long way in terms of identifying the gaps which exist in public policy initiatives for optimum assimilation of religious minorities in Pakistan. The findings show that the sample of this study shares the universal attributes of social groups in terms of factors responsible for social positioning which in contemporary times is widely underscored by the labour market positioning. However, in the context of societies where indigenous minority groups are stranded in lower rungs of social hierarchy for reasons deep rooted in the distant history, upward social mobility becomes an uphill struggle even for the most gifted of their members. The situation of Christians in Pakistan is a case in point. That said, the State of Pakistan owns the responsibility to protect religious minorities and take affirmative action to uplift their disadvantaged members. Specifically, so because the country is Islamic Republic and extending equal opportunities and rights to non-Muslims is religious obligation of the State. Indeed, there have been numerous statutory bodies at both provincial and federal government levels. Unfortunately, most of these public policy initiatives have been unable to deliver cardinal outcomes. Nonetheless, the intent of successive governments in this regard can neither be questioned nor it can be doubted. What remains a major hurdle is the lack of synchronization between intervention schemes at strategic, tactical and operational levels. Most importantly, the demographic information on religious minorities is not available even at the aggregate level, leave alone the segregation with respect to different denominations like rural/urban composition, income groups and occupational categories. At the outset, it appears that a vast majority of the nonMuslim Pakistani workforce is overwhelmingly stranded for generations in low paying menial jobs and lies below the national poverty line. It is therefore important to address impoverished segments of the workforce of religious minorities in Pakistan. This study initially aimed at such an expedition which could not be carried out because the secondary data did not exist, and formidable problems were faced while trying to collect the primary data. The authors therefore decided on a less ambitious research project, embodied in this paper, with the hope that it will help identify almost complete absence of research on social and economic conditions, opportunities and challenges faced by religious minorities in Pakistan. The

\footnotetext{
11 The history of humankind identifies a variety of ways, from assimilation to annihilation, different societies have had recourse to while addressing the question of minorities [see, Daniel and McCauley (2006)]. Spontaneous cultural assimilation is obtained through contact and communication which help improve harmony between the mainstream society and minority groups.
} 
prerequisite for such research undertakings is the existence of reliable secondary data encompassing major demographic characteristics of target groups. 
Personal Traits, Familial Characteristics and Success in the Labor Market: A Survey Study of Christian Labor Force in Pakistan

\section{References}

Abada, T., Hou, F., \& Ram, B. (2008). Ethnic differences in educational attainment among the children of Canadian immigrants. Canadian Journal of Sociology, 34(1), 1-30.

Akinbode, S. (2013). Profiles and determinants of poverty among urban households in South-west Nigeria. American Journal of Economics, 3 (6), 322-329.

Altonji, J. G., \& Blank, R. M. (1999). Race and gender in the labor market. Handbook of labor economics, 3, 3143-3259.

Ayalon, H., Ben-Rafael, E., \& Sharot, S. (1986). The costs and benefits of ethnic identification. British journal of sociology, 550-568.

Banerjee, A. V., \& Duflo, E. (2007). The economic lives of the poor. Journal of economic perspectives, 21(1), 141-168.

Basch, M., \& Paredes-Molina, R. D. (1996). Are there dual labor markets in Chile? empirical evidence. Journal of Development Economics, 50(2), 297-312.

Becker, G. S. (1962). Investment in human capital: A theoretical analysis. Journal of political economy, 70(5, Part 2), 9-49.

Becker, Gary S., and Nigel Tomes. "Human capital and the rise and fall of families." Journal of labor economics 4, no. 3, Part 2 (1986): S1-S39.

Blumer, H. (1986). Symbolic interactionism: Perspective and method. Univ of California Press.

Borjas, G. J. (1987). Immigrants, minorities, and labor market competition. ILR Review, 40(3), 382-392.

Bowles, S. (1973). Understanding unequal economic opportunity. The American Economic Review, 346-356.

Bradley, R. H., Corwyn, R. F., McAdoo, H. P., \& García Coll, C. (2001). The home environments of children in the United States part I: Variations by age, ethnicity, and poverty status. Child development, 72(6), 1844-1867.

Chirot, D., \& McCauley, C. (2010). Why not kill them all?: The logic and prevention of mass political murder. Princeton University Press.

Conger, R. D., \& Donnellan, M. B. (2007). An interactionist perspective on the socioeconomic context of human development. Annu. Rev. Psychol., 58, 175-199. 
Conger, R. D., Conger, K. J., \& Martin, M. J. (2010). Socioeconomic status, family processes, and individual development. Journal of Marriage and Family, 72(3), 685-704.

Conley, D., \& Glauber, R. (2007). Family background, race, and labor market inequality. The ANNALS of the American Academy of Political and Social Science, 609(1), 134-152.

Constant, A., \& Massey, D. S. (2005). Labor market segmentation and the earnings of German guestworkers. Population Research and Policy Review, 24(5), 489-512.

Daw, J., \& Hardie, J. H. (2012). Compensating differentials, labor market segmentation, and wage inequality. Social science research, 41(5), 11791197.

Doeringer, Peter B., and Michael J. Piore. Internal labour markets and manpower analysis. ME Sharpe, 1985.

Fan, C. C. (2002). The elite, the natives, and the outsiders: Migration and labor market segmentation in urban China. Annals of the Association of American Geographers, 92(1), 103-124.

Finnie, R., \& Meng, R. (2002). Minorities, cognitive skills and incomes of Canadians. Canadian Public Policy/Analyse de Politiques, 257-273.

Hadley, C., Belachew, T., Lindstrom, D., \& Tessema, F. (2011). The shape of things to come? Household dependency ratio and adolescent nutritional status in rural and urban Ethiopia. American journal of physical anthropology, 144(4), 643-652.

Hazans, M., Trapeznikova, I., \& Rastrigina, O. (2008). Ethnic and parental effects on schooling outcomes before and during the transition: evidence from the Baltic countries. Journal of Population Economics, 21(3), 719-749.

Hello, E., Scheepers, P., Vermulst, A., \& Gerris, J. R. (2004). Association between educational attainment and ethnic distance in young adults: Socialization by schools or parents?. Acta Sociologica, 47(3), 253-275.

Hirschman, C. (1982). Immigrants and Minorities: Old Questions for Mew Directions in Research. International Migration Review, 16(2), 474-490.

Kim, D. Y., \& Kulkarni, V. S. (2009, March). The Role of Father's Occupation on Intergenerational Educational and Occupational Mobility: The Case of Second-Generation Chinese Americans in New York 1. In Sociological 
Forum (Vol. 24, No. 1, pp. 104-134). Oxford, UK: Blackwell Publishing Ltd.

Maxim, P. S. (1992). Immigrants, visible minorities, and selfemployment. Demography, 29(2), 181-198.

McLeod, J. D., \& Owens, T. J. (2004). Psychological well-being in the early life course: Variations by socioeconomic status, gender, and race/ethnicity. Social Psychology Quarterly, 67(3), 257-278.

Park, C. Y., \& Mercado, R. (2015). Financial inclusion, poverty, and income inequality in developing Asia. Asian Development Bank Economics Working Paper Series, (426).

Poston Jr, D. L. (1994). Patterns of economic attainment of foreign-born male workers in the United States. International Migration Review, 28(3), 478500 .

Ream, R. K., \& Palardy, G. J. (2008). Reexamining social class differences in the availability and the educational utility of parental social capital. American Educational Research Journal, 45(2), 238-273.

Reich, M., Gordon, D. M., \& Edwards, R. C. (1973). A Theory of Labor Market Segmentation The American Economic Review.

Sandefur, G. D., \& Pahari, A. (1989). Racial and ethnic inequality in earnings and educational attainment. Social service review, 63(2), 199-221.

Sanders, J. M. (2002). Ethnic boundaries and identity in plural societies. Annual review of sociology, 28(1), 327-357.

Schneider, B., \& Lee, Y. (1990). A model for academic success: The school and home environment of East Asian students. Anthropology \& Education Quarterly, 21(4), 358-377.

Semyonov, M., \& Lewin-Epstein, N. (1994). Ethnic labor markets, gender, and socioeconomic inequality: A study of Arabs in the Israeli labor force. The Sociological Quarterly, 35(1), 51-68.

Sirin, S. R. (2005). Socioeconomic status and academic achievement: A metaanalytic review of research. Review of educational research, 75(3), 417453. 
Tienda, M., \& Stier, H. (1996). Generating labor market inequality: Employment opportunities and the accumulation of disadvantage. Social Problems, 43(2), 147-165.

Wilson, K. L., \& Portes, A. (1980). Immigrant enclaves: An analysis of the labor market experiences of Cubans in Miami. American journal of sociology, 86(2), 295-319.

Wong, M. G., \& Hirschman, C. (1983). Labor force participation and socioeconomic attainment of Asian-American women. Sociological Perspectives, 26(4), 423-446. 